OPEN ACCESS

Edited by:

John C. Mauro,

Corning Incorporated, USA

Reviewed by:

Takayuki Komatsu,

Nagaoka University

of Technology, Japan

Lina Ma,

Corning Incorporated, USA

*Correspondence:

Markus Rampf

markus.rampf@ivoclarvivadent.com

Specialty section:

This article was submitted

to Glass Science,

a section of the journal

Frontiers in Materials

Received: 29 July 2016 Accepted: 26 September 2016

Published: 17 October 2016

Citation:

Rampf M, Dittmer M, Ritzberger C and Höland W (2016) Controlled Parallel Crystallization

of Lithium Disilicate and

Diopside Using a Combination of Internal and Surface Nucleation.

Front. Mater. 3:47.

doi: 10.3389/fmats.2016.00047

\section{Controlled Parallel Crystallization of Lithium Disilicate and Diopside Using a Combination of Internal and Surface Nucleation}

\author{
Markus Rampf*, Marc Dittmer, Christian Ritzberger and Wolfram Höland \\ Ivoclar Vivadent AG, Schaan, Liechtenstein
}

In the mid-twentieth century, Dr. Donald Stookey identified the importance and usability of nucleating agents and mechanisms for the development of glass-ceramic materials. Today, a number of various internal and surface mechanisms as well as combinations thereof have been established in the production of glass-ceramic materials. In order to create new innovative material properties, the present study focuses on the precipitation of $\mathrm{CaMgSi}_{2} \mathrm{O}_{6}$ as a minor phase in $\mathrm{Li}_{2} \mathrm{Si}_{2} \mathrm{O}_{5}$-based glass-ceramics. In the base glass of the $\mathrm{SiO}_{2}-\mathrm{Li}_{2} \mathrm{O}-\mathrm{P}_{2} \mathrm{O}_{5}-\mathrm{Al}_{2} \mathrm{O}_{3}-\mathrm{K}_{2} \mathrm{O}-\mathrm{MgO}-\mathrm{CaO}$ system, $\mathrm{P}_{2} \mathrm{O}_{5}$ serves as nucleating agent for the internal precipitation of $\mathrm{Li}_{2} \mathrm{Si}_{2} \mathrm{O}_{5}$ crystals, while a mechanical activation of the glass surface by means of ball milling is necessary to nucleate the minor $\mathrm{CaMgSi}_{2} \mathrm{O}_{6}$ crystal phase. For a successful precipitation of $\mathrm{CaMgSi}_{2} \mathrm{O}_{6}$, a minimum concentration of $\mathrm{MgO}$ and $\mathrm{CaO}$ in the range between 1.4 and 2.9 mol\% in the base glasses was determined. The nucleation and crystallization of both crystal phases takes place during sintering a powder compact. Dependent on the quality of the sintering process, the dense $\mathrm{Li}_{2} \mathrm{Si}_{2} \mathrm{O}_{5}-$ $\mathrm{CaMgSi}_{2} \mathrm{O}_{6}$ glass-ceramics show a mean biaxial strength of up to $392 \pm 98 \mathrm{MPa}$. The microstructure of the glass-ceramics is formed by large $(5-10 \mu \mathrm{m})$ bar-like $\mathrm{CaMgSi}_{2} \mathrm{O}_{6}$ crystals randomly embedded in a matrix of small $(\leq 1 \mu \mathrm{m})$ plate-like $\mathrm{Li}_{2} \mathrm{Si}_{2} \mathrm{O}_{5}$ crystals arranged in an interlocking manner. While there is no significant influence of the minor $\mathrm{CaMgSi}_{2} \mathrm{O}_{6}$ phase on the strength of the material, the translucency of the material decreases upon precipitation of the minor phase.

Keywords: glass-ceramics, lithium disilicate, diopside, twofold crystallization, nucleation, surface activation, sintering

\section{INTRODUCTION}

In the 1950s, Dr. Donald Stookey succeeded in the production of the first glass-ceramic of the lithium disilicate type worldwide (Stookey, 1959; Höland and Beall, 2012). His discovery and following research on this new class of materials paved the way for a number of innovative technical solutions affecting daily life, high-tech industry, and fundamental research in various fields. Stove tops and kitchenware belong to the most famous applications of glass-ceramics just as telescope mirrors, the nosecones of spaceships, and dental prostheses (Höland and Beall, 2012). In light of this wide field of applications for Donald Stookey's invention, the impact of his work on not only the technological progress of humankind becomes obvious but also has his research motivated and driven the mind and work of a huge number of scientists in various fields of research ever since. 
In this spirit, the authors of the present publication want to recognize the outstanding activities of Dr. Donald Stookey.

To identify and use the nucleating effect of Ag clusters in the development of glass-ceramics in the $\mathrm{SiO}_{2}-\mathrm{Li}_{2} \mathrm{O}$ system, as well as transferring the general principles of nucleation and crystallization to other glass systems, was a crucial part of his great achievement (Stookey, 1959). Besides enhancing the mechanical strength and machinability of glasses, the precipitation of certain crystal phases helped to control a number of different material properties including optical and electrical properties of glass matrix materials (Beall, 1971, 2014; Mauro et al., 2013).

Initiated after the development of the first lithium disilicate glass-ceramic by Donald Stookey, this system was the subject matter in a multitude of fundamental research topics. A molar ratio $\mathrm{SiO}_{2} / \mathrm{Li}_{2} \mathrm{O}$ of 2 , similar to the stoichiometric composition of lithium disilicate, was the basis for most of the compositions investigated (Höland and Beall, 2012). Moreover, glass-ceramics of the lithium disilicate type from multicomponent base glass systems were developed as well. There, the molar ratio of $\mathrm{SiO}_{2} /$ $\mathrm{Li}_{2} \mathrm{O}$ considerably deviated from the stoichiometric value of 2. Technical glass-ceramics as well as consumer applications were developed this way (Beall, 1992, 2014; Echeverría, 1992). Likewise, Höland et al. (1994, 2005, 2007, 2008, 2009) succeeded in the development of lithium disilicate glass-ceramics for dental applications using such multicomponent base glass systems.

Based on this research and development of lithium disilicate glass-ceramics for dental applications and driven by the quest for innovative combinations of material properties, the authors of the present publication pursued the objective of the parallel controlled nucleation and crystallization of lithium disilicate and diopside $\mathrm{CaMgSi}_{2} \mathrm{O}_{6}$ from a multicomponent base glass. The fundamental extension of the chemical composition of the lithium disilicate base glass system by adding $\mathrm{MgO}$ and $\mathrm{CaO}$ was mandatory just as the enhancement of nucleation and crystallization mechanisms. From a glass-ceramic engineering point of view, the authors assumed that controlling two separate nucleation mechanisms is mandatory to precipitate both a layer silicate and a chain silicate from a base glass. Only the development of a powder compact processing facilitated the crystallization of diopside according to the nucleation and crystallization mechanisms reported by Kokubo et al. (1989), Müller et al. (2000), and Reinsch et al. (2008) for different glass systems. The influence of the parallel precipitation of lithium disilicate and diopside on nucleation and crystallization principles as well as on properties crucial for dental applications, e.g., biaxial strength and translucency, were investigated.

\section{MATERIALS AND METHODS}

\section{Glass Formation and Powder Production}

Four glasses with different compositions in the $\mathrm{SiO}_{2}-\mathrm{Li}_{2} \mathrm{O}-$ $\mathrm{P}_{2} \mathrm{O}_{5}-\mathrm{Al}_{2} \mathrm{O}_{3}-\mathrm{K}_{2} \mathrm{O}-\mathrm{MgO}-\mathrm{CaO}$ system were melted from the raw materials quartz, lithium carbonate, aluminum metaphosphate, aluminum oxyhydroxyhydrate, potassium carbonate, alkaline magnesium carbonate, and calcium carbonate in batches of $100 \mathrm{~g}$ in an uncovered $\mathrm{Pt}-\mathrm{Rh}$ crucible using an electric furnace. The melts were held for $2 \mathrm{~h}$ at $1500^{\circ} \mathrm{C}$ and subsequently casted into water. The glass frit was dried in an oven preheated at $150^{\circ} \mathrm{C}$ for about $2 \mathrm{~h}$. A chemical analysis of the glass frit was conducted by means of X-ray fluorescence (XRF S8 Tiger; Bruker, Karlsruhe, Germany). The dried glass granules were comminuted using a porcelain ball mill loaded with a mixture of steatite, $\mathrm{Al}_{2} \mathrm{O}_{3}$, and porcelain milling beads measuring $10-30 \mathrm{~mm}$ in diameter. Milling was conducted until a mean grain size of $20 \pm 2 \mu \mathrm{m}$ was reached. The grain size distribution was determined using a particle size analyzer (CILAS 1064, Quantachrome GmbH \& Co. KG, Odelzhausen, Germany). Thermal analysis of the glass powder was conducted by means of differential scanning calorimetry (DSC) (STA 449 F3, Netzsch, Selb, Germany) using a heating rate of $10 \mathrm{~K} / \mathrm{min}$. Heating microscope analysis (HMA) was used to investigate the sintering characteristics of the glass powder. Therefore, cylinders of $3 \mathrm{~mm}$ height and a diameter of $2 \mathrm{~mm}$ were pressed and heated with a rate of $10 \mathrm{~K} / \mathrm{min}$ simultaneously recording its silhouettes (EMI V 2.3, Hesse Instruments, Osterode, Germany). The crystallization behavior of the glass powders was investigated by means of high temperature X-ray diffraction (HT-XRD). The glass powder was heated to $400^{\circ} \mathrm{C}$ with a rate of $30 \mathrm{~K} / \mathrm{min}$. Subsequently, the powder was further heated to $1200^{\circ} \mathrm{C}$ in $20 \mathrm{~K}$ steps. Diffraction patterns were recorded from $10^{\circ}$ to $60^{\circ} 2 \theta$ and a step size of $0.014^{\circ}$ with a D8-Advance diffractometer (Bruker, Karlsruhe, Germany) at each step. Therefore, the temperature was held for approximately $30 \mathrm{~min}$ at each step during recording the diffraction pattern. Qualitative analysis was carried out using the software Bruker Diffrac.Suite EVA. The PDF entries 70-4856 $\left(\mathrm{Li}_{2} \mathrm{Si}_{2} \mathrm{O}_{5}\right), 29-0828\left(\mathrm{Li}_{2} \mathrm{SiO}_{3}\right), 15-0760\left(\mathrm{Li}_{3} \mathrm{PO}_{4}\right)$, and 89-0830 $\left(\mathrm{CaMgSi}_{2} \mathrm{O}_{6}\right)$ were used for phase identification.

To investigate the crystallization behavior of the bulk glass A and D, glass was casted into a graphite mold measuring $12 \mathrm{~mm} \times 12 \mathrm{~mm} \times 40 \mathrm{~mm}$ and immediately put in a muffle furnace preheated at $480^{\circ} \mathrm{C}$ for 20 min before slowly cooling the glass in the closed furnace. A disk of approximately $3 \mathrm{~mm}$ thickness was sawn from the glass, heated with a rate of $10 \mathrm{~K} / \mathrm{min}$ to $860^{\circ} \mathrm{C}$ in a furnace of the Programat ${ }^{\circledR}$ type (Ivoclar Vivadent AG, Schaan, Liechtenstein). The temperature was held for $5 \mathrm{~min}$ before slowly opening the oven. One side of the crystallized glassceramic disk was ground using a $125 \mu \mathrm{m}$ diamond grit grinding disk. The ground and the "as fired" surface were analyzed using room temperature XRD applying the parameters described above. Subsequently, the glass-ceramic disk was broken, and the fracture surface was investigated by means of scanning electron microscopy (SEM) after etching for $30 \mathrm{~s}$ with vapor of $40 \%$ hydrofluoric acid and coating with a 1 to $2 \mathrm{~nm} \mathrm{Au-Pd} \mathrm{layer.}$

\section{Production and Sintering of Powder Compacts}

Very small amounts of water, acting as binder, were added to the glass powders before uniaxial pressing of specimen. In this way, powder compacts with different geometries were produced via uniaxial pressing using different press molds. Cubes with an edge length of $18 \mathrm{~mm}$, bars measuring $36 \mathrm{~mm} \times 4.8 \mathrm{~mm} \times 6 \mathrm{~mm}$, and disks with a diameter of 24 and $4 \mathrm{~mm}$ thickness were made. The powder compacts were sintered in vacuum to dense glass-ceramics using a furnace of the Programat ${ }^{\circledR}$ type (Ivoclar Vivadent AG, Schaan, Liechtenstein). The powder compacts were 
heated to $480^{\circ} \mathrm{C}$ with a rate of $30 \mathrm{~K} / \mathrm{min}$ and a subsequent dwell time of $20 \mathrm{~min}$. Subsequently, the powder compact was further heated with $10 \mathrm{~K} / \mathrm{min}$ to $860^{\circ} \mathrm{C}$. This temperature was held for 5 min before slowly opening the furnace and thereby cooling the glass-ceramic to room temperature.

\section{Characterization of the Glass-Ceramics}

Sintered glass-ceramics were pulverized using a mortar grinder (Mortar Grinder RM 200, Retsch, Haan, Germany) and subsequently sieved $<45 \mu \mathrm{m}$. In order to qualitatively investigate the crystal phases, diffraction patterns were recorded from $10^{\circ}$ to $60^{\circ}$ $2 \theta$ applying a step size of $0.014^{\circ}$. Furthermore, a quantitative study of the crystal phase formation was conducted applying Rietveld refinement. Therefore, the pulverized glass-ceramic material was elutriated with approximately $20 \%$ of its mass of $\alpha-\mathrm{Al}_{2} \mathrm{O}_{3}$ (Alfa Aesar, 99.9\%, 20-50 $\mu \mathrm{m} / / \mathrm{ICSD}$ number: 31548 ) as internal standard in acetone. The solvent was evaporated in an oven preheated at $80^{\circ} \mathrm{C}$. After recording the powder XRD patterns from $10^{\circ}$ to $100^{\circ} 2 \theta$ in $0.014^{\circ}$ steps, the quantification of the crystal phases was done with the TOPAS software from Bruker.

The biaxial fracture strength was determined according to ISO 6872 , including a surface finishing with a $15 \mu \mathrm{m}$ diamond grit grinding disk. The specimen were milled from the sintered glassceramic cubes using a CEREC ${ }^{\circledR}$ InLab milling machine (Sirona, Bensheim, Germany). The biaxial strengths are given as mean values of 10 data sets \pm SD.

The thermal expansion of the glass ceramics was determined according to ISO 6872 by applying dilatometric analysis using a sapphire reference. The sintered glass-ceramic bars were ground to the required dimensions using a $40 \mu \mathrm{m}$ diamond grit grinding disk. The error of the measurements is in the range of $\pm 0.5 \times 10^{-6} \mathrm{~K}^{-1}$.

The contrast ratio (CR) of the glass-ceramic disks was determined using a spectrometer of the type CM-3700d (KonicaMinolta, Tokyo, Japan). The sintered disks were prepared according to BS5612. The translucency of a material decreases with increasing $\mathrm{CR}$ value.

Micrographs of the glass-ceramics were taken by means of SEM. The surface of the glass-ceramic samples was therefore polished using a $0.5 \mu \mathrm{m}$ diamond grit grinding disk and subsequently etched with the vapor of $40 \%$ hydrofluoric acid for $30 \mathrm{~s}$.

The porosity of the sintered glass-ceramics was estimated using the line intercept method. Therefore, three fragments of the samples broken within testing the biaxial strength of each glassceramic were polished using a $0.5 \mu \mathrm{m}$ diamond grit grinding disk and examined by SEM. The linear ratio of pores is given as means of three data sets \pm SD.

\section{RESULTS}

\section{Properties and Crystallization Behavior of the Base Glasses}

The chemical composition of the base glasses calculated in mol\% from the results obtained from XRF analysis is given in Table 1. The concentration of $\mathrm{MgO}$ and $\mathrm{CaO}$ in the base glasses increases from glasses $\mathrm{A}$ to $\mathrm{D}$. The results of the thermal analysis of the base glass powders are presented in Figure 1. The glass transition temperatures $T_{\mathrm{g}}$ as well as the exothermic and endothermic peak temperatures are summarized in Table 2. Base glass A shows a $T_{\mathrm{g}}$, which is increased by approximately $10 \mathrm{~K}$ compared to the base glasses B-D. The first exothermic peak temperatures $T_{\text {exol }}$ increase from base glasses $\mathrm{A}$ to $\mathrm{D}$, while the opposite trend can be observed for the second exothermic peak temperatures $T_{\text {exo2. }}$. The third exothermal process can only be detected for the base glasses B-D. Compared to the rather sharp first and second exothermal signals, the third exothermal reaction of the base glasses is characterized by a very wide peak in the temperature range between 780 and $840^{\circ} \mathrm{C}$. The first endothermic heat flow could be detected at approximately $947^{\circ} \mathrm{C}$ for base glass A. Significantly lower endothermic peak temperatures $T_{\text {endol }}$ between 887 and $899^{\circ} \mathrm{C}$ were determined for base glasses B-D. The second endothermic peak $T_{\text {endo2 }}$ could be detected for base glasses B-D.

Figure 2 shows the data obtained by HMA. The area of the silhouette is plotted as a function of the temperature. The first

TABLE 1 | Chemical compositions of the base glasses in $\mathrm{mol} \%$ calculated from the composition determined by XRF analysis.

\begin{tabular}{lrrrr}
\hline & A & B & C & D \\
\hline $\mathrm{SiO}_{2}$ & 64.9 & 62.2 & 61.0 & 60.9 \\
$\mathrm{Li}_{2} \mathrm{O}$ & 25.6 & 25.5 & 25.4 & 25.0 \\
$\mathrm{~K}_{2} \mathrm{O}$ & 2.2 & 2.1 & 2.1 & 2.1 \\
$\mathrm{MgO}$ & 1.4 & 2.9 & 3.6 & 3.8 \\
$\mathrm{CaO}$ & 1.6 & 3.1 & 3.7 & 4.0 \\
$\mathrm{Al}_{2} \mathrm{O}_{3}$ & 2.2 & 2.1 & 2.1 & 2.1 \\
$\mathrm{P}_{2} \mathrm{O}_{5}$ & 2.1 & 2.1 & 2.1 & 2.1
\end{tabular}

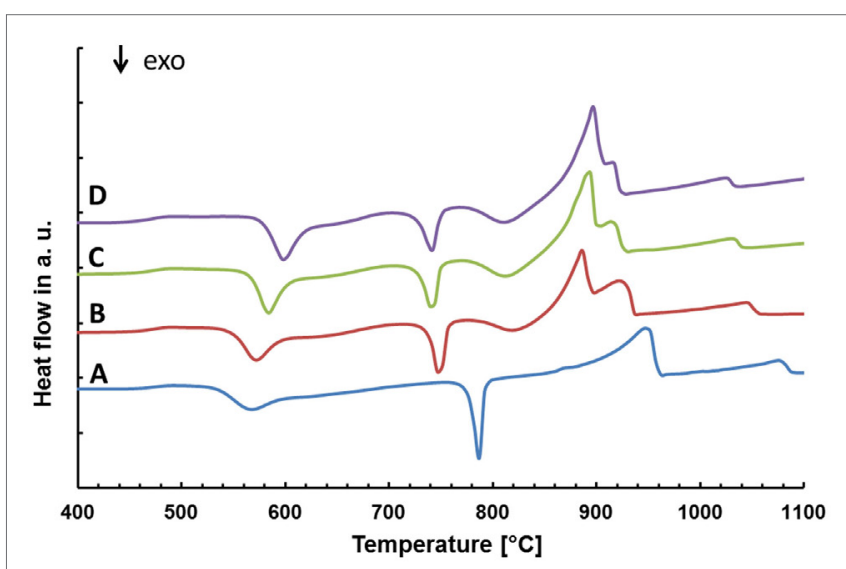

FIGURE 1 | Thermal analysis of the different base glasses.

TABLE 2 | Thermal analysis of the base glasses by means of DSC.

\begin{tabular}{lcccc}
\hline Base glass & A & B & C & D \\
\hline$T_{\mathrm{g}}\left({ }^{\circ} \mathrm{C}\right)$ & 462 & 456 & 456 & 453 \\
$T_{\text {exo1 }}\left({ }^{\circ} \mathrm{C}\right)$ & 568 & 572 & 584 & 599 \\
$T_{\text {exo2 }}\left({ }^{\circ} \mathrm{C}\right)$ & 787 & 750 & 742 & 741 \\
$T_{\text {exo3 }}\left({ }^{\circ} \mathrm{C}\right)$ & - & 819 & 811 & 811 \\
$T_{\text {endo1 }}\left({ }^{\circ} \mathrm{C}\right)$ & 947 & 887 & 893 & 898 \\
$T_{\text {endo2 }}\left({ }^{\circ} \mathrm{C}\right)$ & - & 921 & 914 & 917
\end{tabular}


reduction of the silhouette area occurs for all base glasses in approximately the same temperature range between 500 and $550^{\circ} \mathrm{C}$. After running through a plateau between 550 and $700^{\circ} \mathrm{C}$, the area again decreases for all glasses within the same temperature range between 700 and $800^{\circ} \mathrm{C}$. However, while glasses $\mathrm{B}-\mathrm{D}$

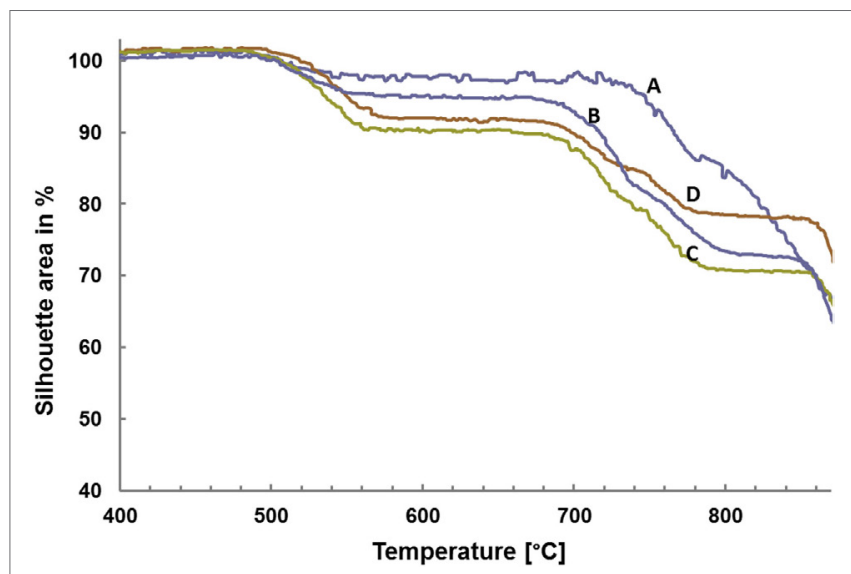

FIGURE 2 | Sintering behavior of the glass powders determined by high temperature microscopy. again show a plateau between 800 and $850^{\circ} \mathrm{C}$, no such second plateau can be found for glass A. A continuous reduction of the shadow area can be observed for all glasses at temperatures exceeding $860^{\circ} \mathrm{C}$.

Diffractograms of glass D obtained by HT-XRD are presented in Figure 3. The diffraction patterns obtained at 29 and $500^{\circ} \mathrm{C}$ reveal no crystalline phases. First indications for the crystallization of $\mathrm{Li}_{2} \mathrm{SiO}_{3}$ could be observed at $540^{\circ} \mathrm{C}$. Characteristic $\mathrm{Li}_{2} \mathrm{Si}_{2} \mathrm{O}_{5}$ peaks could be analyzed in the diffractogram recorded at $680^{\circ} \mathrm{C}$. At $700^{\circ} \mathrm{C}$, no $\mathrm{Li}_{2} \mathrm{SiO}_{3}$ peaks were detected. However, the intensity of the $\mathrm{Li}_{2} \mathrm{Si}_{2} \mathrm{O}_{5}$ peaks is strongly increased and $\mathrm{Li}_{3} \mathrm{PO}_{4}$ can be detected. Reflections characteristic for diopside occur at $760^{\circ} \mathrm{C}$. The intensity of the diopside peaks increases until $860^{\circ} \mathrm{C}$. A similar evaluation of the HT-XRD results obtained for glassceramics A-D is shown in Table 3, where those temperatures are summarized at which a first evidence for the crystallization of a certain crystal phase was found. No diopside formation was detected for glass A. Compared to B-D, glass A shows significantly increased crystallization temperatures for $\mathrm{Li}_{2} \mathrm{SiO}_{3}$ and $\mathrm{Li}_{2} \mathrm{Si}_{2} \mathrm{O}_{5}$.

Investigating the crystallization behavior of the bulk base glass $\mathrm{D}$ by means of room temperature, XRD revealed $\mathrm{Li}_{2} \mathrm{Si}_{2} \mathrm{O}_{5}$ and $\mathrm{CaMgSi}_{2} \mathrm{O}_{6}$ for the "as fired" sample surface. No diopside crystals were detected in the diffraction pattern recorded of the ground sample.

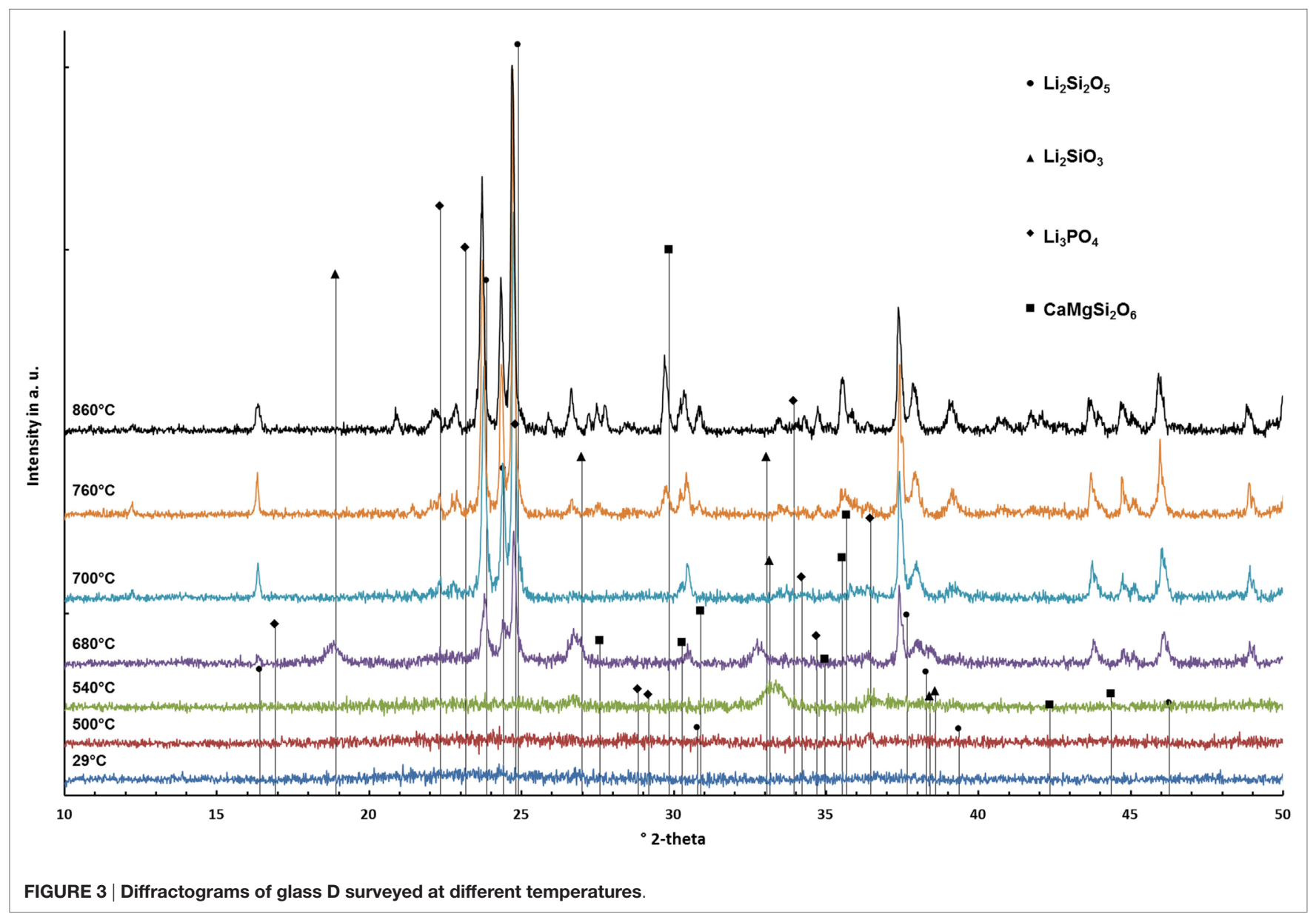


TABLE 3 | Sequence of crystal phase formation as a function of temperature determined by HT-XRD.

\begin{tabular}{lcccc}
\hline & A & B & C & D \\
\hline $\mathrm{Li}_{2} \mathrm{SiO}_{3}\left({ }^{\circ} \mathrm{C}\right)$ & 520 & 520 & 520 & 540 \\
$\mathrm{Li}_{2} \mathrm{Si}_{2} \mathrm{O}_{5}\left({ }^{\circ} \mathrm{C}\right)$ & 740 & 680 & 680 & 680 \\
$\mathrm{Li}_{3} \mathrm{PO}_{4}\left({ }^{\circ} \mathrm{C}\right)$ & 760 & 700 & 700 & 700 \\
$\mathrm{CaMgSi}_{2} \mathrm{O}_{6}\left({ }^{\circ} \mathrm{C}\right)$ & - & 740 & 740 & 760 \\
\hline
\end{tabular}

The additional investigation of the micrograph of the fracture surface in Figure 4 shows small $(\leq 1 \mu \mathrm{m})$ plate-like crystals in the bulk of the material and large bar-like crystals growing from the surface into the bulk of the material. The investigation of bulk base glass $\mathrm{A}$ revealed solely the formation of $\mathrm{Li}_{2} \mathrm{Si}_{2} \mathrm{O}_{5}$, and no surface crystallization of diopside could be observed.

\section{Characterization of the Glass-Ceramics}

Diffraction patterns of the sintered glass-ceramics recorded at room temperature are shown in Figure 5. $\mathrm{Li}_{2} \mathrm{Si}_{2} \mathrm{O}_{5}$ and $\mathrm{Li}_{3} \mathrm{PO}_{4}$ could be detected in all glass-ceramics. However, glass-ceramics $\mathrm{B}-\mathrm{D}$ reveal the presence of diopside.

The results of the quantitative crystal phase analysis by means of Rietveld refinement are shown in Table $4 . \mathrm{Li}_{2} \mathrm{Si}_{2} \mathrm{O}_{5}$ is the main crystal phase in the glass-ceramics. The content of $\mathrm{Li}_{2} \mathrm{Si}_{2} \mathrm{O}_{5}$ decreases from $\mathrm{A}$ to $\mathrm{D}$, while the content of diopside increases from $\mathrm{B}$ to $\mathrm{C}$. With respect to the accuracy of measurement and refinement, there is no difference in the ratio of diopside in glassceramics C and D. Glass-ceramic A comprises a considerably higher ratio of amorphous residual glass phase than $\mathrm{B}-\mathrm{D}$.

Micrographs of the glass-ceramics A-D displayed in Figure 6 reveal an interlocking microstructure of small $(\leq 1 \mu \mathrm{m})$ plate-like crystals. The microstructure of glass-ceramics B-D additionally comprises bar-like crystals with a length between 3 and $10 \mu \mathrm{m}$. The large bar-like crystals are randomly distributed within the microstructure. The analysis of the porosity revealed thoroughly dense glass-ceramics $\mathrm{A}$ and $\mathrm{D}$, while $\mathrm{B}$ and $\mathrm{C}$ showed a linear ratio of pores of $4.5 \pm 3.4$ or $0.9 \pm 0.4 \%$, respectively.

The biaxial strength of the glass-ceramics is presented in Table 5. Glass-ceramic D shows the highest mean biaxial strength. With respect to the SD of the measurement results, the biaxial strength of glass-ceramic D is significantly higher than that of glass-ceramics B and C. The strength of glass-ceramics A and D is in a similar range.

No significant difference in the thermal expansion properties of the different glass-ceramics could be analyzed. The results are presented in Table 5. $\mathrm{CTE}_{25-500^{\circ} \mathrm{C}}$ values in the range between $9.8 \times 10^{-6} \mathrm{~K}^{-1}$ and $10.2 \times 10^{-6} \mathrm{~K}^{-1}$ were determined.

All glass-ceramics show a low degree of translucency. Glassceramic A revealed a considerably lower opacity than glassceramics B-D, which are rather similar (Table 5).

\section{DISCUSSION}

The extension of the chemical composition of the base glass by certain amounts of $\mathrm{MgO}$ and $\mathrm{CaO}$ is the prerequisite for the precipitation of $\mathrm{CaMgSi}_{2} \mathrm{O}_{6}$ as a minor crystal phase in $\mathrm{Li}_{2} \mathrm{Si}_{2} \mathrm{O}_{5}$ glass-ceramics. Increasing the content of $\mathrm{MgO}$ and $\mathrm{CaO}$ from

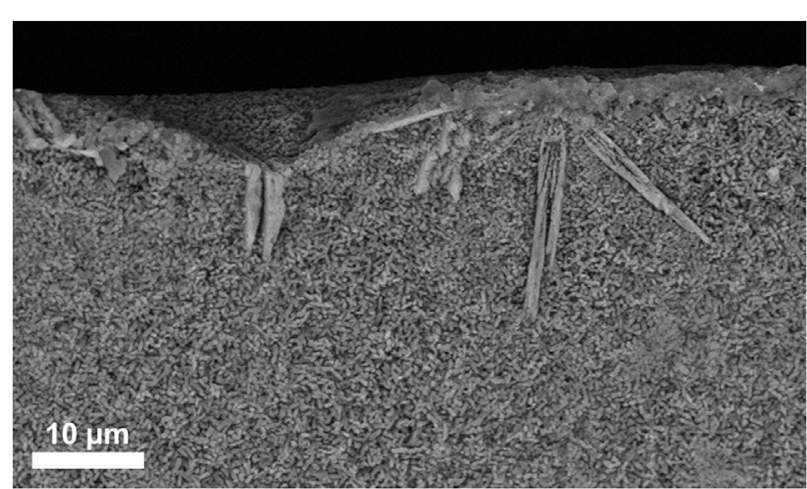

FIGURE 4 | SEM micrograph taken from the fracture surface of a bulk base glass sample $D$ crystallized at $860^{\circ} \mathrm{C}$ for $5 \mathrm{~min}$.

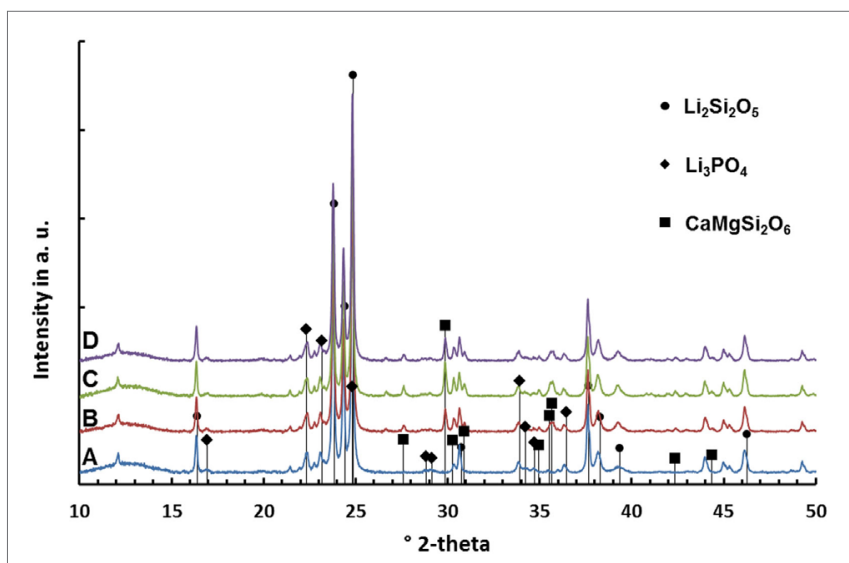

FIGURE 5 | Diffractograms of glass-ceramics after sintering at $860^{\circ} \mathrm{C}$ for $5 \mathrm{~min}$.

TABLE 4 | Quantitative composition of glass-ceramics after sintering and crystallization at $860^{\circ} \mathrm{C}$ for $5 \mathrm{~min}$ (ICSD number).

\begin{tabular}{lccrr}
\hline & A & B & C & D \\
\hline wt.\% $\mathrm{Li}_{2} \mathrm{Si}_{2} \mathrm{O}_{5}(280481)$ & 47.8 & 45.7 & 45.2 & 43.2 \\
wt.\% $\mathrm{CaMgSi}_{2} \mathrm{O}_{6}(10222)$ & - & 7.4 & 10.8 & 10.5 \\
wt.\% $\mathrm{Li}_{3} \mathrm{PO}_{4}(50058)$ & 9.1 & 8.8 & 8.6 & 8.2 \\
wt.\% amorphous phase & 43.1 & 38.2 & 35.4 & 38.1 \\
\hline
\end{tabular}

approximately 1.4 to $2.9 \mathrm{~mol} \%$ yielded the precipitation of diopside in the present study. However, no internal nucleation and crystallization of diopside was found in the present base glasses, but surface crystallization of diopside could be verified in the preliminary study of the crystallization behavior of the bulk base glass D (Figure 4). Hence, an activation of the glass surface was mandatory to nucleate the crystallization of diopside. In the present study, the activation of the glass surface was achieved by means of ball milling. It is important to note that the magnitude of activation of a glass surface is strongly dependent on the method and processing parameters used. There exist a lot of different milling techniques as well as there are various alternative ways to 


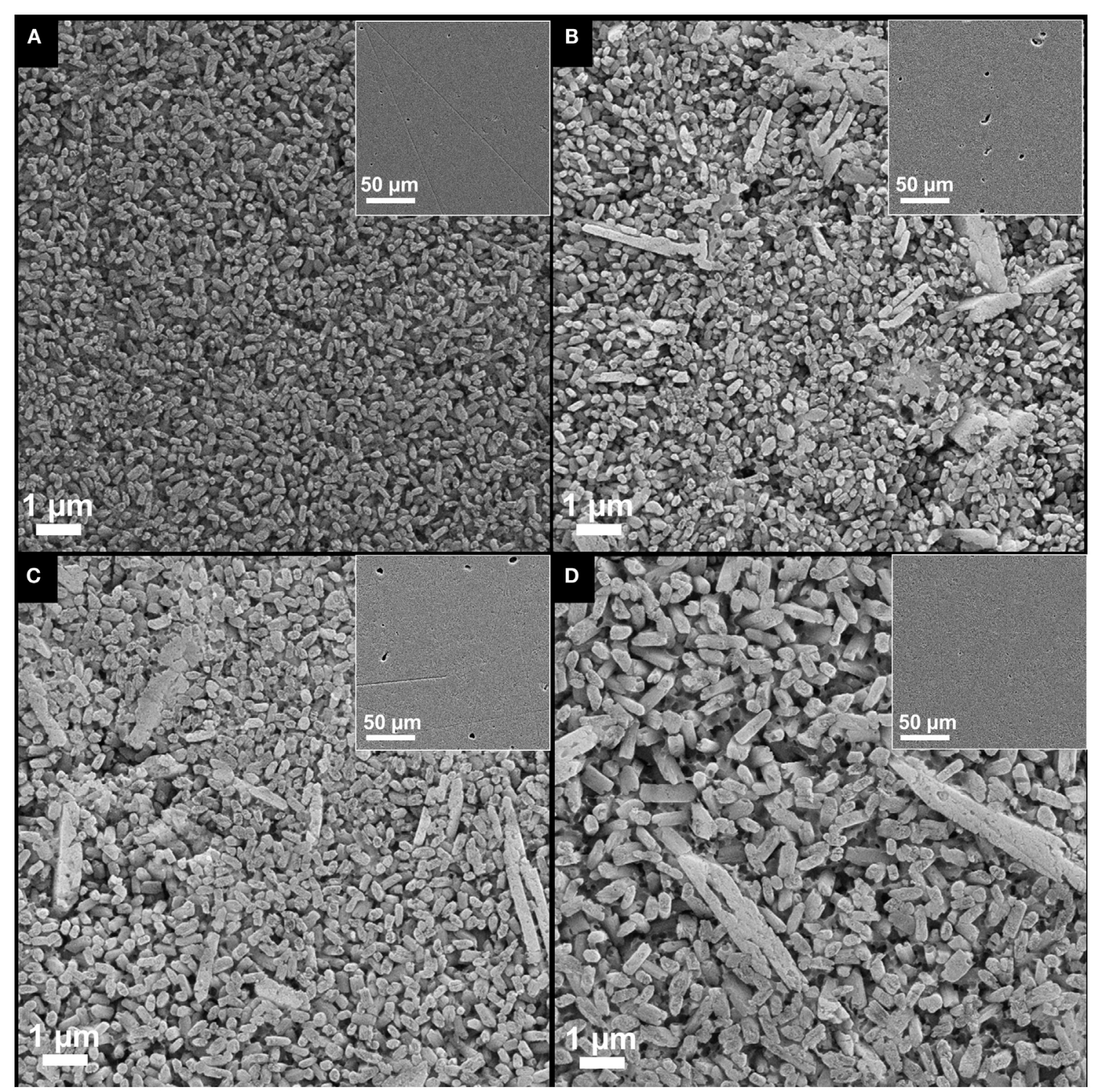

FIGURE 6 | Micrographs of the glass-ceramics (A-D) after sintering at $860^{\circ} \mathrm{C}$ for $5 \mathrm{~min}$.

initiate surface nucleation and crystallization for different material systems, e.g., by means of tribochemistry (Henicke, 1984). Hence, the concentration of $\mathrm{MgO}$ and $\mathrm{CaO}$ that is mandatory for the crystallization of diopside can deviate dependent on the method used for the activation of the glass surface.

The analysis of the base glasses by means of DSC (Figure 1; Table 2) reveals two rather sharp exothermal peaks for all the base glasses. According to the data obtained by HT-XRD (Table 3), these peaks can be correlated to the crystallization of $\mathrm{Li}_{2} \mathrm{SiO}_{3}$ and $\mathrm{Li}_{2} \mathrm{Si}_{2} \mathrm{O}_{5}$. The rather sharp characteristic of these peaks suggests that an internal nucleation and crystallization mechanism is dominant. The effect of $\mathrm{P}_{2} \mathrm{O}_{5}$ as internal nucleating agent for lithium silicates at a glassy amorphous interphase was previously reported in literature (Höland and Beall, 2012). HT-XRD studies in the present glass-ceramics reveal that crystalline $\mathrm{Li}_{3} \mathrm{PO}_{4}$ can only be detected after heat treatments above $700^{\circ} \mathrm{C}$, whereas the crystallization of $\mathrm{Li}_{2} \mathrm{SiO}_{3}$ already starts at $\geq 520^{\circ} \mathrm{C}$ (Table 3). Hence, a mechanism reported by Höland and Beall (2012) describing the nucleation of lithium silicate at the interphase of a glassy amorphous or disordered nanocrystalline early phase of $\mathrm{Li}_{3} \mathrm{PO}_{4}$ seems most likely.

A rather wide exothermal signal in the DSC curves of glass B-D between 780 and $860^{\circ} \mathrm{C}$ are an indication for a surface nucleation and crystallization mechanism. The data obtained by HT-XRD show that diopside forms in exactly this temperature range. Hence, the authors conclude that diopside crystallizes on the activated surface of the glass grains. Furthermore, surface nucleation and crystallization display well-known mechanisms found in the investigations on diopside glass-ceramics (Kokubo et al., 1989; Zanotto, 1991; Müller et al., 2000). 
TABLE 5 | Properties of the glass-ceramics.

\begin{tabular}{lcccc}
\hline & A & B & C & D \\
\hline$\sigma_{\text {biax }}(\mathrm{MPa})$ & $329 \pm 67$ & $270 \pm 60$ & $262 \pm 71$ & $391 \pm 98$ \\
$\mathrm{CR}(\%)$ & 77 & 88 & 92 & 92 \\
$\mathrm{CTE}_{25-500^{\circ} \mathrm{C}} \times 10^{-6} \mathrm{~K}^{-1}$ & 10.2 & 10.1 & 9.8 & 9.8
\end{tabular}

In summary, the precipitation of two different silica-based crystal phases from the present glass system requires the control of two essentially different nucleation mechanisms. On the one hand, the layer silicate $\mathrm{Li}_{2} \mathrm{Si}_{2} \mathrm{O}_{5}$ is nucleated by an internal nucleation mechanism, and on the other hand, surface activation nucleates the crystallization of the chain silicate $\mathrm{CaMgSi}_{2} \mathrm{O}_{6}$.

To produce bulk glass-ceramics from internal and surface crystallizing base glasses, a powder compact process was developed. Crystallization of the glass powder and sintering of the powder compacts to achieve dense bulk glass-ceramics has to be controlled in parallel. Analyzing the sintering behavior of the glass powders by means of HMA (Figure 2), together with the results of the HT-XRD studies (Table 3), was the basis to develop an adequate firing cycle. According to the HMA curves, densification starts at approximately $500^{\circ} \mathrm{C}$ for all base glasses. Since the $T_{\mathrm{g}}$ of the base glass powders is between 450 and $460^{\circ} \mathrm{C}$, the starting densification is clearly a result of the softening and beginning viscous flow of the glass. Crystallization of $\mathrm{Li}_{2} \mathrm{SiO}_{3}$ and $\mathrm{Li}_{2} \mathrm{Si}_{2} \mathrm{O}_{5}$ between 540 and $700^{\circ} \mathrm{C}$ clearly increase the viscosity of the glasses and hence stop the densification as can be seen in the first plateau of the HMA curve. Base glasses B-D show a second plateau ending at approximately $855^{\circ} \mathrm{C}$, which can be explained by the crystallization of diopside hindering the sintering process. Dissolution of crystal phases and melting of the glass-ceramics begins at temperatures $>860^{\circ} \mathrm{C}$.

Based on these results, the crystallization and sintering cycle of the powder compacts was developed. It starts with a fast heating to $480^{\circ} \mathrm{C}$, where the temperature is kept for $20 \mathrm{~min}$ in order to internally nucleate lithium silicate at a glassy amorphous $\mathrm{P}_{2} \mathrm{O}_{5}$-rich interface (Höland and Beall, 2012). After internal nucleation, the powder compacts were heated to $860^{\circ} \mathrm{C}$ with a reduced heating rate of $10 \mathrm{~K} / \mathrm{min}$. Crystallization and sintering takes place in this temperature range. To obtain a dense glass-ceramic with minimal crystal phase dissolution and viscous deformation of the specimen, the sintering cycle stops after a dwell time of $5 \mathrm{~min}$ at $860^{\circ} \mathrm{C}$. The micrographs of the glass-ceramics in Figure 6 reveal pores in the glass-ceramics $\mathrm{B}$ and C. Glass-ceramics A and D show a more homogeneous and dense microstructure than the other glass-ceramics. Based on the quantitative crystal phase analysis of the glass-ceramics (Table 4) and assuming that the entire ratio of amorphous $\mathrm{P}_{2} \mathrm{O}_{5}-\mathrm{Li}_{2} \mathrm{O}$ phase precipitates to $\mathrm{Li}_{3} \mathrm{PO}_{4}$, one can roughly estimate the composition of the residual glass phases. The estimated composition of residual glass phase is shown in Table 6. According to this estimation, the residual glass phase of the glass-ceramic $\mathrm{D}$ comprises a considerably higher concentration of network modifiers such as $\mathrm{Li}_{2} \mathrm{O}, \mathrm{MgO}$, and $\mathrm{CaO}$. This would result in a reduced viscosity of the residual glass phases compared to glass-ceramics $\mathrm{A}-\mathrm{C}$ and therefore displays an interesting point
TABLE 6 | Estimated chemical compositions of the residual glass phases in $\mathrm{mol} \%$.

\begin{tabular}{lccrr}
\hline & A & B & C & D \\
\hline $\mathrm{SiO}_{2}$ & 76.4 & 73.3 & 71.9 & 70.1 \\
$\mathrm{Li}_{2} \mathrm{O}$ & 4.4 & 7.5 & 9.0 & 9.7 \\
$\mathrm{~K}_{2} \mathrm{O}$ & 5.7 & 6.2 & 6.6 & 6.1 \\
$\mathrm{MgO}$ & 3.7 & 3.0 & 2.7 & 3.4 \\
$\mathrm{CaO}$ & 4.1 & 3.7 & 3.1 & 4.2 \\
$\mathrm{Al}_{2} \mathrm{O}_{3}$ & 5.7 & 6.3 & 6.7 & 6.2 \\
$\mathrm{P}_{2} \mathrm{O}_{5}$ & - & - & - & 0.3 \\
\hline
\end{tabular}

of discussion regarding the sintering properties of the glassceramics. Comparing the sintering properties of glass-ceramic $\mathrm{A}$ to $\mathrm{B}$ and $\mathrm{C}$, the restraining influence of crystallization processes on the sintering process becomes obvious, since glass-ceramic A shows no diopside formation in contrast to B and C. A more dedicated investigation is necessary to resolve the different results of the sintering process. Furthermore, enhancing the powder processing, e.g., by granulation of the glass powder prior to uniaxial pressing, could improve the densification and sintering of the powder compacts.

The influence of the chemical composition of the base glasses on the quantitative crystal phase composition of the final glassceramics is shown in Table 4. Obviously, a concentration of $\leq 1.4$ or $1.6 \mathrm{~mol} \%$ of $\mathrm{MgO}$ and $\mathrm{CaO}$ in the base glasses is insufficient for the precipitation of $\mathrm{CaMgSi}_{2} \mathrm{O}_{6}$ in the present base glass system. However, as mentioned in the first paragraph of the discussion, this finding is only true for the activation of the glass powders surface by means of ball milling down to a mean grain size of about $20 \mu \mathrm{m}$. Increasing the concentration of $\mathrm{MgO}$ and $\mathrm{CaO}$ from 2.9 or 3.1 to 3.6 or $3.7 \mathrm{~mol} \%$, respectively, resulted in a considerable increase of the diopside content by $3.4 \mathrm{wt} . \%$, while further increasing to 3.8 or $4 \mathrm{~mol} \%$, respectively, did not significantly change the concentration of diopside in the glass ceramic. The reduced content of $\mathrm{SiO}_{2}$ together with the consumption of $\mathrm{SiO}_{2}$ during the crystallization of $\mathrm{Li}_{2} \mathrm{Si}_{2} \mathrm{O}_{5}$ could explain the stagnant precipitation of $\mathrm{CaMgSi}_{2} \mathrm{O}_{6}$, although higher concentrations of $\mathrm{CaO}$ and $\mathrm{MgO}$ are provided in the base glass.

Based on the preliminary study of crystallization (Figure 4) and comparing the micrographs $\mathrm{B}-\mathrm{D}$ with the micrograph of the diopside-free glass-ceramic A (Figure 6), the crystals forming the microstructure of the glass-ceramics can be identified. Large $(5-10 \mu \mathrm{m})$ bar-like diopside crystals are embedded in a matrix of rather small $(<1 \mu \mathrm{m})$ plate-like $\mathrm{Li}_{2} \mathrm{Si}_{2} \mathrm{O}_{5}$ crystals (Figure 6).

High concentrations of crystalline phases ( $>55$ wt.\%) (Table 4) as well as the arrangement of $\mathrm{Li}_{2} \mathrm{Si}_{2} \mathrm{O}_{5}$ and $\mathrm{CaMgSi}_{2} \mathrm{O}_{6}$ crystals in an interlocking microstructure (Figure 6) contribute to the biaxial strength of the glass-ceramics (Dittmer et al., 2014). However, pores in the microstructure, as they were found particularly in glass-ceramics B and C (Figure 6), can decrease the biaxial strength of the materials. In a previous study on tailoring, the thermal expansion of $\mathrm{Li}_{2} \mathrm{Si}_{2} \mathrm{O}_{5}$ glass-ceramics by precipitating a high CTE minor phase significant effects on the biaxial strength of the glass-ceramics due to the considerable mismatch in the CTEs of the involved crystal phases were reported (Rampf et al., 2015, 2016). However, in the glass-ceramic system investigated 
in the present study, such effects are unlikely since there is no such huge difference in the thermal expansion of the involved crystal phases. The $\mathrm{CTE}_{200-800^{\circ} \mathrm{C}}$ of diopside crystals was investigated to be approximately $7.4 \times 10^{-6} \mathrm{~K}^{-1}$ (Rigby and Green, 1942) and therefore very close to polycrystalline lithium disilicate $\left(\mathrm{CTE}_{25-600^{\circ} \mathrm{C}}=11.4 \times 10^{-6} \mathrm{~K}^{-1}\right)$ compared to the investigations by Rampf et al. (2015, 2016).

The precipitation of diopside as a minor phase in $\mathrm{Li}_{2} \mathrm{Si}_{2} \mathrm{O}_{5}$ glassceramics reduces the translucency of the glass-ceramic materials due to the introduction of a further interface where scattering of light occurs (Nassau, 2001). The influence of a minor crystal phase $\mathrm{Ca}_{5}\left(\mathrm{PO}_{4}\right)_{3} \mathrm{~F}$ on the optical properties of $\mathrm{Li}_{2} \mathrm{Si}_{2} \mathrm{O}_{5}$ glass-ceramics was previously investigated by Rampf et al. (2015, 2016). They reported the optical properties, in particular the translucency, to be dominated by the $\mathrm{Li}_{2} \mathrm{Si}_{2} \mathrm{O}_{5}$ crystals, which appeared to be significantly larger than the submicron sized apatite crystals. However, the apatite crystals having dimensions in the range of visible light did affect the opalescence of the materials. In the present system, the diopside crystals are significantly larger than the approximately $0.5-1 \mu \mathrm{m}$-sized $\mathrm{Li}_{2} \mathrm{Si}_{2} \mathrm{O}_{5}$ crystals. Hence, the precipitation of diopside displays an effective tool to influence the translucency of $\mathrm{Li}_{2} \mathrm{Si}_{2} \mathrm{O}_{5}$ glass-ceramics without affecting its opalescence properties.

Machining of the crystallized glass-ceramics using conventional CAD/CAM technology was feasible without problems. The minor diopside phase enhanced the machinability of the $\mathrm{Li}_{2} \mathrm{Si}_{2} \mathrm{O}_{5}$ glass-ceramics probably by interfering with the high-strength interlocking $\mathrm{Li}_{2} \mathrm{Si}_{2} \mathrm{O}_{5}$ microstructure.

\section{CONCLUSION}

Glass-ceramics comprising $\mathrm{Li}_{2} \mathrm{Si}_{2} \mathrm{O}_{5}$ as main crystal phase and $\mathrm{CaMgSi}_{2} \mathrm{O}_{6}$ as minor crystal phase can be produced from base glasses in the $\mathrm{SiO}_{2}-\mathrm{Li}_{2} \mathrm{O}-\mathrm{P}_{2} \mathrm{O}_{5}-\mathrm{Al}_{2} \mathrm{O}_{3}-\mathrm{K}_{2} \mathrm{O}-\mathrm{MgO}-\mathrm{CaO}$ system. The parallel precipitation of a layer silicate $\left(\mathrm{Li}_{2} \mathrm{Si}_{2} \mathrm{O}_{5}\right)$ on the one side and crystals of the chain silicate type $\left(\mathrm{CaMgSi}_{2} \mathrm{O}_{6}\right)$ on

\section{REFERENCES}

Beall, G. H. (1971). "Structure, properties, and nucleation of glass-ceramics," in Advances in Nucleation and Crystallization in Glasses, 8 Edn, Vol. Special Publ. 5, eds L. L. Hench and S. S. Freiman (Columbus, OH: The Am. Ceram. Soc.), 251-261.

Beall, G. H. (1992). Design and properties of glass-ceramics. Annu. Rev. Mater. Sci. 22, 91-119. doi:10.1146/annurev.ms.22.080192.000515

Beall, G. H. (2014). Milestones in glass-ceramics - a personal perspective. Int. J. Appl. Glass-Sci. 5, 1-11. doi:10.1111/ijag.12063

Dittmer, M., Ritzberger, C., Schweiger, M., Rheinberger, V., Wörle, M., and Höland, W. (2014). Phase and microstructure formation and their influence on the strength of two types of glass-ceramics. J. Non-Cryst. Solids 384, 55-60. doi:10.1016/j.jnoncrysol.2013.03.009

Echeverría, L. M. (1992). New lithium disilicate glass-ceramic. Bol. Soc. Ceram. Vid. 5, 183-188.

Henicke, G. (1984). Tribochemisty. München, Wien: Carl Hanser Verlag.

Höland, W., and Beall, G. H. (2012). Glass-Ceramic Technology. Hoboken, NJ: Wiley.

Höland, W., Frank, M., Schweiger, M., and Rheinberger, V. (1994). "Development of translucent glass-ceramics for dental applications," in Proceedings of the $5^{\text {th }}$ International Otto Schott Colloquium, ed. C. Rüssel (Frankfurt: Verlag der Deutschen Glastechnischen Gesellschaft), 117-121. the other side require the control of two separate nucleation and crystallization mechanisms. $\mathrm{Li}_{2} \mathrm{Si}_{2} \mathrm{O}_{5}$ can be nucleated internally at an amorphous glassy $\mathrm{P}_{2} \mathrm{O}_{5}-\mathrm{Li}_{2} \mathrm{O}$-rich interphase. The activation of the glass surface, e.g., by means of ball milling, is mandatory to efficiently nucleate the crystallization of $\mathrm{CaMgSi}_{2} \mathrm{O}_{6}$.

The chemical composition, in particular a sufficient concentration of $\mathrm{MgO}$ and $\mathrm{CaO}$, of the base glass is essential for the precipitation of the $\mathrm{CaMgSi}_{2} \mathrm{O}_{6}$ minor phase. However, the mandatory concentration of $\mathrm{MgO}$ and $\mathrm{CaO}$ can deviate with the extent or method applied for surface activation.

A reproducible powder compact process, including uniaxial pressing and sintering, was developed to produce dense $\mathrm{Li}_{2} \mathrm{Si}_{2} \mathrm{O}_{5}$ $\mathrm{CaMgSi}_{2} \mathrm{O}_{6}$ glass ceramic materials.

$\mathrm{Li}_{2} \mathrm{Si}_{2} \mathrm{O}_{5}-\mathrm{CaMgSi}_{2} \mathrm{O}_{6}$ glass-ceramics could be machined by means of conventional CAD/CAM technology and reach a biaxial strength of $391 \pm 98 \mathrm{MPa}$ based on the interlocking microstructure and possible additional compressive stress formation.

The large $(5-10 \mu \mathrm{m})$ bar-like $\mathrm{CaMgSi}_{2} \mathrm{O}_{6}$ crystals embedded in a matrix of interlocking $(\leq 1 \mu \mathrm{m}) \mathrm{Li}_{2} \mathrm{Si}_{2} \mathrm{O}_{5}$ crystals reduce the translucency of the material and hence display a further potential tool to create new combinations of material properties within $\mathrm{Li}_{2} \mathrm{Si}_{2} \mathrm{O}_{5}$-based glass-ceramics.

\section{AUTHOR CONTRIBUTIONS}

MR: planning, organization, and execution of experiments; interpretation and discussion of results; and compilation of manuscript and artwork. MD: execution of Rietveld refinement; interpretation and discussion of results on XRD analysis; and assistance in compilation of the manuscript. CR: consulting in planning of experiments; interpretation and discussion of HMA and DSC; and assistance in compilation of the manuscript. WH: consulting regarding the state of the art literature on the topic; interpretation and discussion of results; and assistance in the compilation and proofreading of the manuscript.

Höland, W., Rheinberger, V., Apel, E., and van't Hoen, C. (2007). Principles and phenomena of bioengineering with glass-ceramics for dental restorations. J. Eur. Ceram. Soc. 27, 1521-1526. doi:10.1016/j.jeurceramsoc.2006.04.101

Höland, W., Rheinberger, V., van't Hoen, C., and Apel, E. (2005). $\mathrm{P}_{2} \mathrm{O}_{5}$ as an effective nucleating agent of lithium disilicate glass-ceramics. Phosphorus Res. Bull. 19, 36-41. doi:10.3363/prb1992.19.0_36

Höland, W., Schweiger, M., Rheinberger, V. M., and Kappert, H. (2009). Bioceramics and their application for dental restoration. Adv. Appl. Ceram. 108, 373-380. doi:10.1179/174367609X414099

Höland, W., Schweiger, M., Watzke, R., Peschke, A., and Kappert, H. (2008). Ceramics as biomaterials for dental restoration. Expert Rev. Med. Devices 5, 729-745. doi:10.1586/17434440.5.6.729

Kokubo, T., Sakka, S., Sako, W., and Ikejiri, S. (1989). Preparation of glass-ceramic containing crystalline apatite and magnesium titanate for dental crown. J. Ceram. Soc. Jpn. Ed. 97, 236-240.

Mauro, J. C., Ellison, A. J., and Pye, L. D. (2013). Glass: the nanotechnology connection. Int. J. Appl. Glass-Sci. 4, 64-75. doi:10.1111/ijag.12030

Müller, R., Zanotto, E. D., and Fokin, V. M. (2000). Surface crystallization of silicate glasses: nucleation sites and kinetics. J. Non-Cryst. Solids 274, 208-213. doi:10.1016/S0022-3093(00)00214-3

Nassau, K. (2001). The Physics and Chemistry of Color. Hoboken, NJ: Wiley.

Rampf, M., Dittmer, M., Ritzberger, C., Schweiger, M., and Höland, W. (2015). Properties and crystallization phenomena in $\mathrm{Li}_{2} \mathrm{Si}_{2} \mathrm{O}_{5}-\mathrm{Ca}_{5}\left(\mathrm{PO}_{4}\right)_{3} \mathrm{~F}$ and 
$\mathrm{Li}_{2} \mathrm{Si}_{2} \mathrm{O}_{5}-\mathrm{Sr}_{5}\left(\mathrm{PO}_{4}\right)_{3} \mathrm{~F}$ glass-ceramics via twofold internal crystallization. Front. Bioeng. Biotechnol. 3:122. doi:10.3389/fbioe.2015.00122

Rampf, M., Fisch, M., Dittmer, M., Ritzberger, C., and Höland, W. (2016). Tailoring the thermal expansion of glass-ceramics by controlled twofold crystallization of $\mathrm{Li}_{2} \mathrm{Si}_{2} \mathrm{O}_{5}$ and $\mathrm{CsAlSi}_{5} \mathrm{O}_{12}$. Int. J. Appl. Glass Sci. 7, 285-294. doi:10.1111/ ijag. 12180

Reinsch, S., Nascimento, M. L. F., Müller, R., and Zanotto, E. D. (2008). Crystal growth kinetics in cordierite and diopside glasses in wide temperature ranges. J. Non-Cryst. Solids 354, 5386-5394. doi:10.1016/j.jnoncrysol.2008.09.007

Rigby, G. R., and Green, A. T. (1942). The thermal expansion characteristics of some calcareous and magnesium minerals. Trans. Br. Ceram. Soc. 41, 123-143.

Stookey, S. D. (1959). Catalyzed crystallization of glass in theory and practice. Ind. Eng. Chem. 51, 805-808. doi:10.1021/ie50595a022

Zanotto, E. D. (1991). Surface nucleation of diopside glass. J. Non-Cryst. Solids 130, 217-219. doi:10.1016/0022-3093(91)90458-I
Conflict of Interest Statement: The authors are employees of the company Ivoclar Vivadent AG. A patent was filed on the present subject.

The reviewer LM and handling Editor declared their shared affiliation, and the handling Editor states that the process nevertheless met the standards of a fair and objective review.

Copyright $\odot 2016$ Rampf, Dittmer, Ritzberger and Höland. This is an open-access article distributed under the terms of the Creative Commons Attribution License (CC BY). The use, distribution or reproduction in other forums is permitted, provided the original author(s) or licensor are credited and that the original publication in this journal is cited, in accordance with accepted academic practice. No use, distribution or reproduction is permitted which does not comply with these terms. 